\title{
BIM LOD FOR FACILITY MANAGEMENT TASKS
}

\author{
Seyed Hamidreza Alavi, and Nuria Forcada Matheu \\ Universitat Politècnica de Catalunya, Dept. of Construction Engineering, \\ Terrassa, Barcelona, Spain
}

\begin{abstract}
Building information modeling (BIM) widely adopted in design and construction phase of the buildings, holds undeveloped possibilities for supporting Facility Management (FM) tasks in Operation \& Maintenance (O\&M) phase. The purpose of this paper is to define appropriate Level of Development (LOD) for different FM areas in order to enable FM-BIM for existing buildings during O\&M phase. To do so, the customized LOD have been defined by existing literature review and facility experts. Then the required properties for each FM areas are implemented in two case studies. Conclusion demonstrated that more than 60 percent of properties defined as LOD500 are unnecessary to execute FM tasks. Besides, the categories of Services including Mechanical, Electrical and Plumbing (MEP) and fire systems requires more properties comparing with another categories and it needs specific LOD to leverage BIM in O\&M phase.
\end{abstract}

\section{Introduction}

Throughout the lifecycle of the buildings, the highest costs occur during the phase of Operation \& Maintenance (O\&M) (Brito and Pereira 2017) since some reports (Akcamete et al. 2010c; Teicholz 2013a) show that more than 60 percent of a total project cost is related to this phase which emphasize the importance of Facility Management (FM) tasks.

Building information modeling (BIM) has been emerging as a potential solution for Facility Managers (FMs) to address the challenges of information reliability, interoperability and usability in providing the project to endorse the lifecycle of their assets' information (Liu and Issa 2016). One of the advantages of BIM is to share data among multiple systems during the O\&M phase (Motawa and Almarshad 2013). BIM has potential to support FM tasks by acting as a data repository, by locating equipment within a facility, and by coordinating information from multiple systems (Becerik-Gerber et al. 2012a). In order to enable BIM for FMs, it is absolutely crucial to access appropriate and reliable information to operate and maintain equipment and systems efficiently in the building to extend the lifespan of equipment, to support decision making, to improve maintenance activities, to make energy more efficient, and to minimize labor time and equipment downtime (Cavka et al. 2017). Despite the numerous benefits offered by BIM, its utilization for the O\&M phase remains significantly limited (Pishdad-Bozorgi et al. 2018). A serious hindrance to enabling BIM for FMs is the challenge of identifying and formalizing the information requirements needed to support FM tasks (Cavka et al. 2017) especially for existing buildings.

International Facility Management Association (IFMA) defined Facility Management as a profession that encompasses multiple disciplines to ensure functionality of the built environment by integrating people, place, process and technology. International facility management ISO standards presents different areas of FM (IFMA 2016) such as Asset Management (ISO 55001), Energy Management (ISO 50001), Safety Management (ISO 45001), Security Management (ISO 27001), etc.

According to Becerik (2012), these areas could be implemented in a BIM model and taken advantage of BIM during O\&M phase, on the basis of the feedback gathered from the current and future implementers of BIM-enabled FM practices, and from persona and expert interviews.

In an effort to enable FM-BIM, each one of these FM areas demanded precise information (Becerik-Gerber et al. 2012a) which required defining Level of Development (LOD) (Leite et al. 2011). The LOD designation for project milestones determine geometric and non-geometric attribute information offered by a model component ((AIA) 2008). For instance, the Construction Operations Building information exchange (COBie) defines a LOD for technical equipment for commissioning maintenance functionalities with respect to type, location, serial numbers, tag, installation date, warranty, plan of maintenance necessity (The National Institute of Building Sciences 2013). However, LOD specification does not objective what FM tasks require as facility information (Dias and Ergan 2016). Most of researchers (Bruno et al. 2018; Chen et al. 2018; Lijun 
et al. 2016; Pärn et al. 2017; Pishdad-Bozorgi et al. 2018) allocated LOD 500 for FM tasks which possess too much information, whilst having too much of unrequired information makes it challenging to manage (Cavka et al. 2017).

The aim of this paper is to overcome these challenges and determine appropriate LOD for different areas of FMs (Asset Management, Energy Management, Safety Management, Security Management, Space Management, Maintenance, Operation and Monitoring) so as to be able to take advantage of full value of BIM in O\&M phase of the buildings.

\section{Background}

\section{BIM in project lifecycle}

The utilization of BIM in the design and construction phases has been conducted by enormous researchers and the professional communities. Researchers have focused on implementing BIM on design (Eastman et al. 2008; Kiziltas and Akinci 2010), automated cost estimation, visualization of process (Babič et al. 2010; Sacks et al. 2010). Enabling BIM for keeping and maintaining information has also been one of the most commonly researched areas in O\&M phase (Hwang and Liu 2010). Moreover, BIM implementations have also been extended to energy analysis (Chew et al. 2004; Stumpf et al. 2009) and sustainability (Arayici et al. 2011; Barnes and Castro-Lacouture 2009; Sacks et al. 2009). Recently, using BIM in the other fields has been central in research such as valuable 'as-built BIM' (Volk et al. 2014), maintenance of warranty and service information (Arayici 2008; Becerik-Gerber and Rice 2010; Singh et al. 2011), quality control (Boukamp and Akinci 2007), assessment management and monitoring (Arayici 2008; Becerik-Gerber et al. 2012b), energy management and space management (Becerik-Gerber et al. 2012b; Cho et al. 2010), emergency management (Arayici 2008) or retrofit planning (Mill et al. 2013). Furthermore, making decisions on preventive maintenance plan (Akcamete et al. 2010a; Becerik-Gerber et al. 2012a; Teicholz 2013b), building systems analysis (Becerik-Gerber et al. 2012a; Weygant 2011), and commissioning processes (Becerik-Gerber et al. 2012a; Jiao et al. 2013; Weygant 2011), emergency planning and strategies plan (Becerik-Gerber et al. 2012a; Zou and Wang 2009) can benefit from BIM in O\&M phase.

\section{FM-BIM for new and existing buildings}

Recently, with the growing interest in enabling BIM for FMs, many researchers (Akcamete et al. 2010b; Pishdad-Bozorgi et al. 2018) have focused on transferring information from design phase to O\&M phase. For this purpose, some standards are used to transfer information from design phase to O\&M phase such as Industry Foundation Classes (IFC) (IFC 2016), COBie (COBie 2017), etc. The Industry Foundations Classes (IFC) is an open, neutral and standardized specification for Building Information Models allows AEC to utilize various software during whole lifecycle of the buildings. According to National Building Specification, COBie is a non-proprietary data format for the publication of a subset of BIM focused on delivering asset data as distinct from geometric information. It reduces the time and effort that the FMs spend on entering building information manually. However, it allows to possess too much information result in overloading (Anderson et al. 2012; Thabet et al. 2016) Accordingly, COBie needs to be customized for facility information as a means to building operation (Dias and Ergan 2016).

In contrast, for existing buildings, if BIM model is not available, the buildings should be modelled from the scratch. In this regard, techniques of data capture or survey are applied (Donath 2009). However, These kind of information is spread out and might not be available in many existing buildings due to lack of asbuilt, CAD files (Becerik-Gerber et al. 2012b; Gursel et al. 2009) along with imperfect and deficient, obsolete or disintegrated building information (Gursel et al. 2009). If BIM model is available, it comes from design and construction phase of the buildings which typically do not contain the necessary information for executing FM tasks (Dias and Ergan 2016).

\section{LOD for FMs}

Some researchers (Dias and Ergan 2016; Liu and Issa 2016; Sattenini et al. 2011; Terreno et al. 2015; Thabet et al. 2016) have attempted to determine LOD needed for O\&M phase by interviewing experts. Liu and Issa (2016) conducted a survey questionnaire to define a list of maintenance problems such as Lack of equipment accessibility, poor design of equipment layout, lack of adequate space for mechanical room, lack of space designed in the ceiling to contain MEP systems, limited space for AHU filter access that ought to be deliberated in design phase. Sattenini et al. (2011) interviewed with facility managers of Auburn university for defining required information to be included in a BIM model. Thabet et al. (2016) depicted workflow for collecting information defining who is responsible and when data should be collected during project lifecycle. Regarding maintenance management area of FM, Akcamete et al. (2010) have been utilizing BIM model in an university campus for enabling maintenance planning and linking maintenance history to facilitate decision making . Cavka et al. (2017) developed owner information requirements for enabling BIM to assist maintenance (preventive schedule-periodic reactive), building systems monitoring (operation/monitoring and tracking) and asset management. Accordingly, there is a lack of generally LOD that can apply to each kind of FM areas to manage the buildings efficiently.

\section{Methodology}

In order to determine the appropriate LOD for the different areas of FM, each element of the building (such as Air Handling Unit, chiller, steam boiler, floor, etc.) should have suitable geometric representation and 
properties extracted from Omniclass, COBie, Specifiers' Properties information exchange (SPie) to be included in BIM models. Based on detailed examination of Omniclass, COBie, Spie, the authors allocated facility properties represented in these standards for each elements (Figure 1).

The authors focused on the most important elements that are common or typically seen in different buildings. The Uniformat classification is used to classify elements into five categories: 1) Substructure; 2) Shell (Exterior, Windows, Doors, Roof, Column, and Beam); 3) Interiors (Wall, Ceiling); 4) Services (HVAC, Plumbing, Air handling unit, Chiller, Electrical); 5) Equipment \& Furnishing. Table 1 shows the elements in each categories based on Uniformat classification.

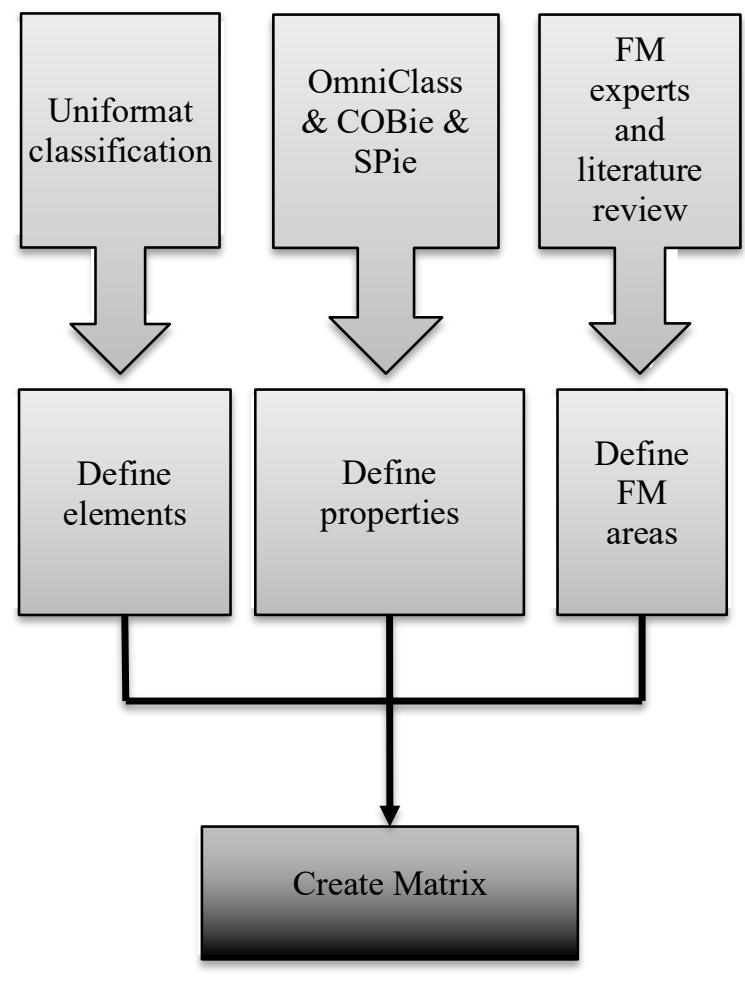

Figure 1: Process of creation a matrix

The focus group was conducted with twelve FM experts including engineers, architects and technicians who were involved in FM services and consultancy (Bortolini and Forcada 2018) both to define FM areas and eliminate unnecessary properties (to avoid heavy model so as to be used in FM tasks). The experts included 8 industrial engineers, one architect, two quantity surveyors, and one technical engineer.

Experts agreed that the most relevant FM areas include: Asset Management, Energy Management, Safety Management, and Security Management, Maintenance, Space Management, Operation and Monitoring. Based on these FM areas, elements and properties, the elements-LOD matrix is created (Figure
1). The FM experts identified what properties with their geometric representation are relevant in BIM model so as to leverage BIM for FM areas. Figure 2 shows the elements-LOD matrix with respect to FM areas.

The feasibility of implementing the proposed LOD was then validated in two case studies by collecting the required elements' properties from two university buildings from the Universitat Politècnica de Catalunya (UPC), Spain.

Table 1: Elements in each categories

\begin{tabular}{|c|c|c|}
\hline Categories & $\begin{array}{c}\text { Group } \\
\text { Elements }\end{array}$ & $\begin{array}{l}\text { Individual } \\
\text { Elements }\end{array}$ \\
\hline Substructure & Foundation & Foundation \\
\hline \multirow{8}{*}{ Shell } & \multirow{3}{*}{ Superstructure } & Column \\
\hline & & Beam \\
\hline & & Floor \\
\hline & \multirow{4}{*}{$\begin{array}{l}\text { Exterior } \\
\text { Enclosure }\end{array}$} & Wall exterior \\
\hline & & Curtain wall \\
\hline & & Window \\
\hline & & Door \\
\hline & Roofing & Roof \\
\hline \multirow{2}{*}{ Interiors } & $\begin{array}{c}\text { Interior } \\
\text { Construction }\end{array}$ & Wall interior \\
\hline & $\begin{array}{l}\text { Interior } \\
\text { Finishes }\end{array}$ & Ceiling \\
\hline \multirow{8}{*}{ Services } & Conveying & $\begin{array}{c}\text { Elevators \& } \\
\text { Lifts }\end{array}$ \\
\hline & Plumbing & $\begin{array}{l}\text { Plumbing } \\
\text { Fixtures }\end{array}$ \\
\hline & \multirow{4}{*}{ HVAC } & $\begin{array}{c}\text { Air handling } \\
\text { unit }\end{array}$ \\
\hline & & Chiller \\
\hline & & Steam boiler \\
\hline & & Water heater \\
\hline & Fire Protection & $\begin{array}{c}\text { Fire protection } \\
\text { systems }\end{array}$ \\
\hline & Electrical & $\begin{array}{c}\text { Electrical } \\
\text { systems }\end{array}$ \\
\hline \multirow{2}{*}{$\begin{array}{c}\text { Equipment \& } \\
\text { Furnishing }\end{array}$} & Equipment & Objects \\
\hline & Furnishings & $\begin{array}{c}\text { Fixed } \\
\text { furnishing }\end{array}$ \\
\hline
\end{tabular}




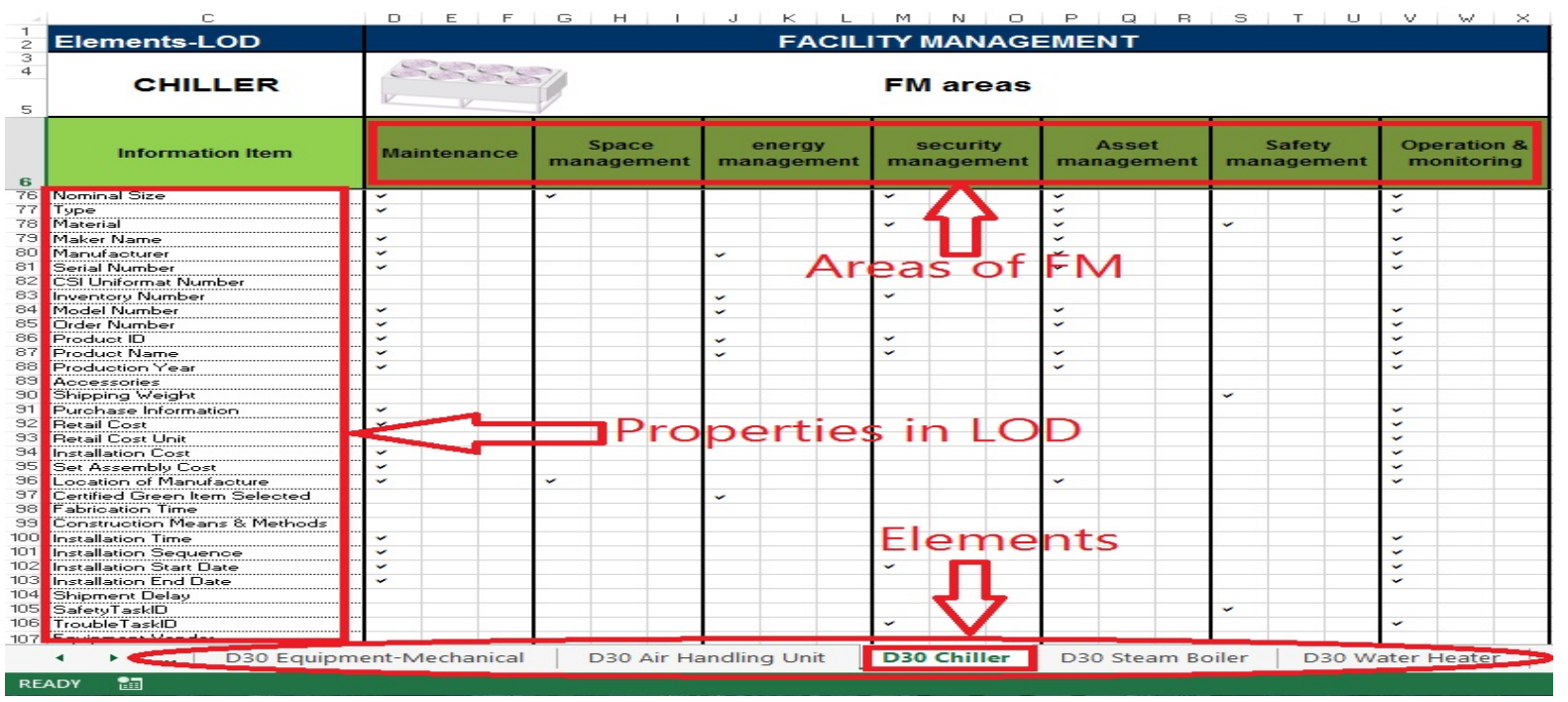

Figure 2: The elements-LOD matrix

\section{Results}

The properties collected from OmniClass, COBie, SPie for LOD500 contain approximately more than 8000 properties. After eliminating those properties that FM experts found irrelevant for managing buildings, the number of properties fell dramatically to approximately 3000 properties. It shows that more than 60 percent of properties are unnecessary to execute FM tasks.

Figure 3 illustrates the properties for each categories based on FM areas. For the Operation and Monitoring activites, a huge amount of information (elements' properties) within the "Services" category is needed. Monitoring electrical, gas, water consumptions are also important for this FM area.

In the area of Safety management, the categories of "services" and "shell" are those that require more properties. Taking into account that it is urgent to access the information organized and displayed logically to respond and take appropriate actions during an actual emergency (Becerik-Gerber et al. $2012 b$ ), most of the properties requirements for safety management are of a spatial nature (e.g. evacuation routing position). Other properties are related to Fire Resistance, Fire Prevention, Disability Access, Occupancy/Capacity, Means of Egress, Fire Rating Requirement, Building Type Selection, and Position of fire extinguishers and defibrillators.

In the area of Asset management, "equipment and furnishing" is the category that requires by far more properties. These properties mainly include Maintenance history, Maintenance schedule. schedule ID, Approve By, Delivery, Schedule Activity,

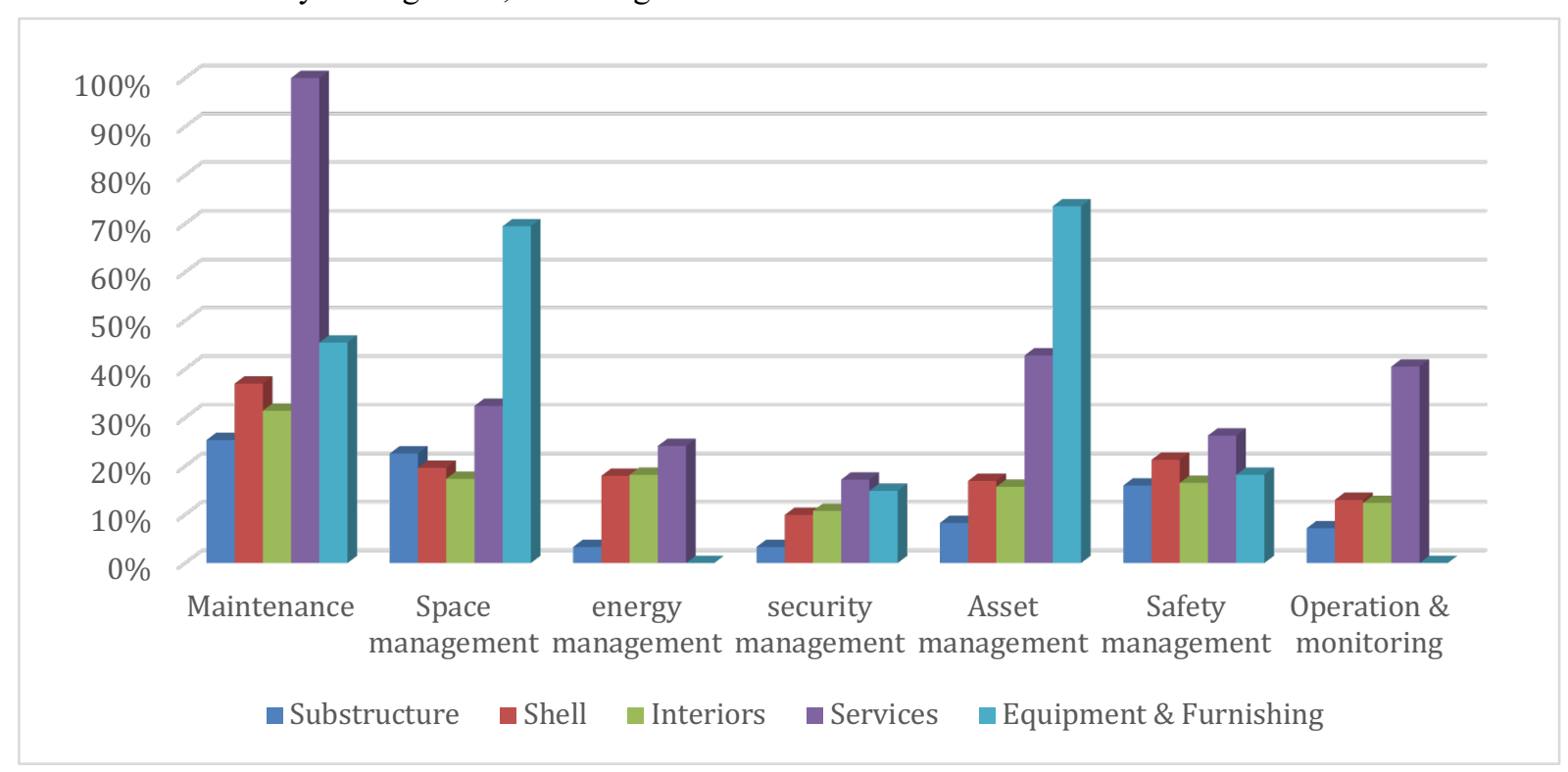

Figure 3: Properties for each categories based on FM areas 
Inspection report, system lists, equipment lists, Component ID, Component Name, Component Description, Attribute ID, System Reference ID, Maker Name , Manufacturer Serial Number, installation manual, Inventory Number, Model Number, Order Number, Product ID, Maintenance history, Purchase Information, Retail Cost, Retail Cost Unit, Installation Cost, Type, Material, Availability, etc. Whether public or private sector, and whether assets are physical, financial, human or 'intangible', asset management could maximize value-for-money. It involves coordinated and optimized planning, asset selection, acquisition/development, utilization, care and ultimate disposal or renewal of assets and asset systems (Asset management standards).

For the management of security, all categories except "substructure" require approximately a similar amount of properties for "equipment and furnishing", "interiors", "services" and "shell". Security in operation typically addresses certain aspects of IT or data security.

In the area of Energy management, the most relevant properties are related to the categories of "services". "Interiors" and "shell" held the same amount of properties. The most relevant properties for Energy management are, Air Infiltration, Low E Glazing, Energy Efficiency Ratio, R-Value, U-Value, System performance, Absorption-Value, Radiation Exposure, Green Material Type, Green Material Specification, Power consuming, Recycled Content, Post-Industrial Recycled Content, Pre-Consumer Recycled Content, Post-Consumer Recycled Content, Carbon Footprint, Certified Green, Item Selected, Coefficient of Performance, etc. Using energy efficiently helps organizations save money as well as helping to conserve resources and tackle climate change.

In the area of Maintenance, the "services" requires more properties as might be expected followed by the category of "equipment \& furnishing". In this case, the LOD properties for "Services" consist of Shape, location of panel and valves, Component ID, Room Number, Room Name, Story Number, Manufacturer Name, Product Name, Type, Acquisition Date, Bar Code, Serial Number, Assembly Place, Production Year, Warranty Identifier, Warranty Start Date, Warranty End Date, Warranty Period, Contact, etc. Building maintenance combines actions to keep the building in an appropriate condition for use (Shohet et al. 2003), including technical building inspections that characterize a building's pathological state.

In the area of Space management, the category of "equipment \& furnishing" demands more properties. FMs are able to optimize the physical utilization of the spaces and related assets. Remodeling or renovating of existing buildings is also considered in this area (Space management). Facility ID, Facility, Name, Length, Width, Height, Area, Volume, Maximum Size, Story Number, Zone/Space Name, Zone/Space Number,
Room Name, Room Number, Floor ID, Floor Name, Space Volume, Room Name Tag, Glazing Requirements, Net to Gross Space Requirement, Ceiling Height, Building Story Information, space ID, Space Number, Coordinate ID, Coordinate Type, etc. are the most relevant properties for Space management.

The findings indicate that there are huge amount of information which are not necessary for implementing FM tasks and it causes heavy BIM model (creating model navigation and computer memory issues). Generally, the elements which require more properties are related to the categories of "Services" including Mechanical, Electrical and Plumbing (MEP) and fire systems and they need specific LOD to be used in BIM model. "Equipment and Furnishing" is also important for asset management and space management.

\section{Case study}

The feasibility of implementing the proposed LOD is validated by collecting the required elements' properties from two university buildings from the Universitat Politècnica de Catalunya (UPC), Spain. Both buildings (TR5 and Gaia) are located in Campus Terrassa and are managed by the same Facility Management department. The campus includes 25 buildings of different typologies and construction ages. There are buildings with more than 100 years and buildings with less than 10 years. About $98 \%$ of the buildings have the energy consumption monitored, $60 \%$ of the buildings have automated HVAC systems and only $20 \%$ of the buildings have automated lighting (Bortolini et al. 2016).

The majority of the building characteristics of the campus (age of construction, location, type of materials, technology of the equipment, etc.,) are stored in pdf files in an intranet platform called Somdoc. This platform also includes maintenance reports, guarantees, etc.

Building monitoring and control data (temperature, humidity, energy consumption, etc.) is automatically captured by sensor, sent to a Building Management System (BMS) (TAC VISTA Schneider) and visualized in an intranet application.

The water and energy consumption is monitored by Power Studio ${ }^{\circledR}$ and visualized on the intranet platform called Sirena (System of Information on Consumption of Energy Resources and Water). 
Regarding the maintenance management, the university campus uses Archibus ${ }^{\circledR}$ system, which consist of a Computer Automated Facility Management (CAFM) and Integrated Workplace Management System (IWMS) for FM. The visualization of information is text based and includes 2D drawings of the buildings. For asset management, UPC campus adopted a standardized classification of elements. All building elements and systems are classified with a predefined code based on COBie. The structure of information has a standard classification and it is organized by: campus, building, floor, room and type of element.

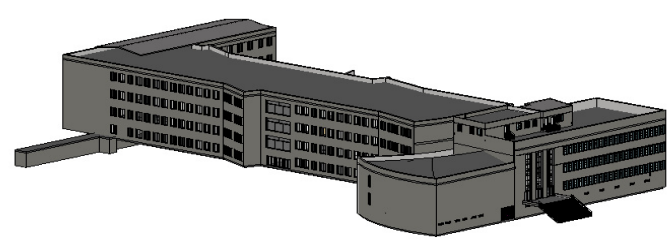

Figure 4: TR5 modelled in Revit

TR5 was built in 1960 and is mainly used for classes. Although having temperature and humidity sensors in different areas of the building, the automation of the systems is low. There is neither light control nor automatic HVAC system. Only architectural and systems CAD drawings are available. These drawings include very basic information such as the location of equipment but without specifying their characteristics. These CAD drawings are not updated and might contain dimensional errors. Figure 4 shows TR5 modelled in Revit based on existing information.

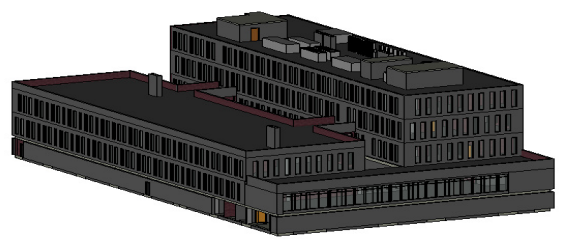

Figure 5: Gaia modelled in Revit

Gaia was built in 2006 and is mainly used for offices. It is a highly automated building with HVAC and lighting control. As-built drawings and maintenance manuals are precise. The architectural BIM model is also available, although some construction properties and building systems are missing. Figure 5 shows Gaia BIM model.

Table 2 demonstrate the available properties in each building. As it can be seen, Gaia has nearly most of the properties required in each category. On the other hand, TR5 needs more properties to leverage BIM for
FM areas. The available properties for the service category is only $40 \%$ in TR5. Hence, facility managers miss necessary properties for FM operation.

Table 2: Available properties in TR5 \& Gaia

\begin{tabular}{|l|c|c|}
\hline \multicolumn{1}{|c|}{ Categories } & TR5 & Gaia \\
\hline Substructure & $67 \%$ & $90 \%$ \\
\hline Shell & $64 \%$ & $87 \%$ \\
\hline Interiors & $58 \%$ & $84 \%$ \\
\hline Services & $40 \%$ & $72 \%$ \\
\hline Equipment \& Furnishing & $70 \%$ & $84 \%$ \\
\hline
\end{tabular}

The available properties of each category in TR5 and Gaia buildings are compared. The results show that Gaia building has approximately all the necessary properties and has potential to improve the building performance by implementing other FM areas, while TR5 needs more properties which requires either time or specific tools to obtain that properties since it does not have an as-built document. Moreover, most of the available properties in TR5 are obsolete and need to be updated. Although Gaia has got most of the properties, these properties are stored in different platform and needs to be store in one platform to be more useful for other FM areas. For instance, facility managers can make decision on replace equipment or remodel a building if they have an access to reliable information provided in BIM.

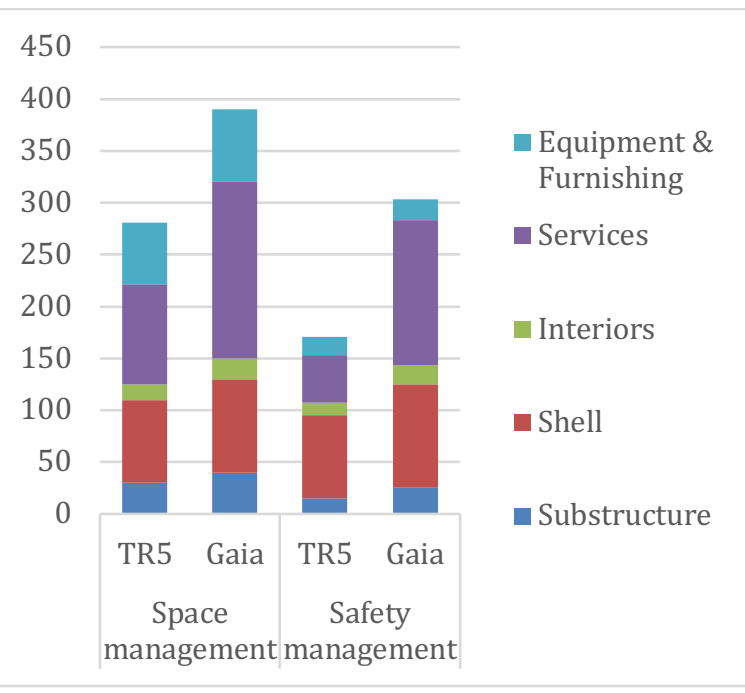

Figure 6: The available properties in TR5 and Gaia with respect to space and safety management

Regarding Space management and safety management in both buildings (Figure 6), the availability of properties in the category of interiors are quite the same. The same situation happened in Equipment \& Furnishing category where TR5 and Gaia buildings possess the same amount of properties with respect to FM areas (space and safety management), even though space management area requires more properties other than safety management area in this category.

As it can be seen in Figure 6, the significantly different 
in properties available between TR5 and Gaia buildings are related to the service category. Table 3 illustrates more than $70 \%$ of properties are not available in TR5 for service category in order to implement safety management area.

Table 3: Available properties in TR5 \& Gaia with respect to Space and Safety management areas of FM

\begin{tabular}{|l|l|l|l|l|}
\hline \multirow{2}{*}{ Categories } & \multicolumn{2}{c|}{$\begin{array}{c}\text { Space } \\
\text { management }\end{array}$} & \multicolumn{2}{c|}{$\begin{array}{c}\text { Safety } \\
\text { management }\end{array}$} \\
\cline { 2 - 5 } & TR5 & Gaia & TR5 & Gaia \\
\hline Substructure & $73 \%$ & $98 \%$ & $52 \%$ & $86 \%$ \\
\hline Shell & $84 \%$ & $95 \%$ & $78 \%$ & $97 \%$ \\
\hline Interiors & $71 \%$ & $95 \%$ & $60 \%$ & $90 \%$ \\
\hline Services & $49 \%$ & $87 \%$ & $29 \%$ & $88 \%$ \\
\hline $\begin{array}{l}\text { Equipment } \\
\text { furnishing }\end{array}$ & $71 \%$ & $83 \%$ & $82 \%$ & $91 \%$ \\
\hline
\end{tabular}

Safety management area is ignored in both buildings, however, Gaia has potential to implement this FM area based on the properties available, $86 \%$ in substructure, 97\% shell, 90\% interiors, $88 \%$ services, 91\% equipment and furnishing. Although space management area in TR5 and Gaia buildings is already implemented, it is becoming more evident that both buildings can improve this area activities with having more certain properties.

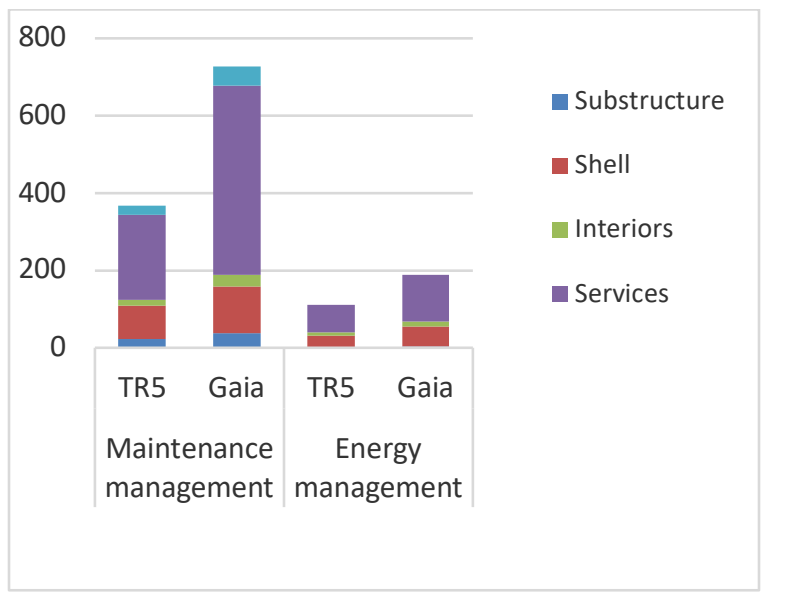

Figure7: The available properties in TR5 and Gaia with respect to maintenance and energy management

Regarding Maintenance and Energy management (Figure 7), the Gaia building has got approximately $80 \%$ of the properties in each categories for maintenance area. However, more than $50 \%$ properties in TR 5 building are not available and FMs will not be able to execute maintenance tasks completely. to Maintenance and Energy management areas of FM

\begin{tabular}{|l|c|c|c|c|}
\hline \multirow{2}{*}{ Categories } & \multicolumn{2}{|c|}{$\begin{array}{c}\text { Maintenance } \\
\text { management }\end{array}$} & \multicolumn{2}{c|}{$\begin{array}{c}\text { Energy } \\
\text { management }\end{array}$} \\
\cline { 2 - 5 } & TR5 & Gaia & TR5 & Gaia \\
\hline Substructure & $50 \%$ & $83 \%$ & $33 \%$ & $67 \%$ \\
\hline Shell & $47 \%$ & $67 \%$ & $34 \%$ & $57 \%$ \\
\hline Interiors & $39 \%$ & $79 \%$ & $36 \%$ & $64 \%$ \\
\hline Services & $36 \%$ & $81 \%$ & $48 \%$ & $82 \%$ \\
\hline $\begin{array}{l}\text { Equipment \& } \\
\text { Furnish }\end{array}$ & $45 \%$ & $91 \%$ & & \\
\hline
\end{tabular}

The properties available for energy management in both buildings are quite low (Table 4). FMs should come up with getting information so as to implement energy management area.

\section{Discussion}

The LOD defined for each areas of FM can bring benefit to FMs to utilize BIM model with full value. For example, the availability of the relevant properties on "Services" can not only improve the maintenance area but also the energy management area. The location of plumbing can not only be used for maintenance but also can be used for safety and energy management areas. Hence, facility managers knows what properties are missing and they would be able to decide whether they require it or not with respect to FM areas. BIM model, which contain appropriate LOD, can be used for maintenance activities, monitoring energy consumption, and etc. Having all these necessary information conjointly will enable FMs to make decisions. For instance, having information about consumption, occupancy, façade along with historic information about complains for one room, FMs would find out where the problem comes from and decide whether it is better to stop the air conditioning or replace the window to reduce energy consumption.

Figure 8 shows the difference BIM creation between new and existing buildings. In many existing buildings, BIM is not available and the properties should be collected from existing information (Paper, maintenance history, walk through the building, etc.) which might not be reliable or updated. Even if the BIM model is available, it might not be used for FM tasks in O\&M phase. For instance, In design phase, generally, the architectural model might lack adequate detail and information about building systems and equipment data, many facility elements are not modelled due to either complexity of the modelling process, or they are considered nonessential to design drawings and visualization (Sacks et al. 2018). In

Table 4: Available properties in TR5 \& Gaia with respect 


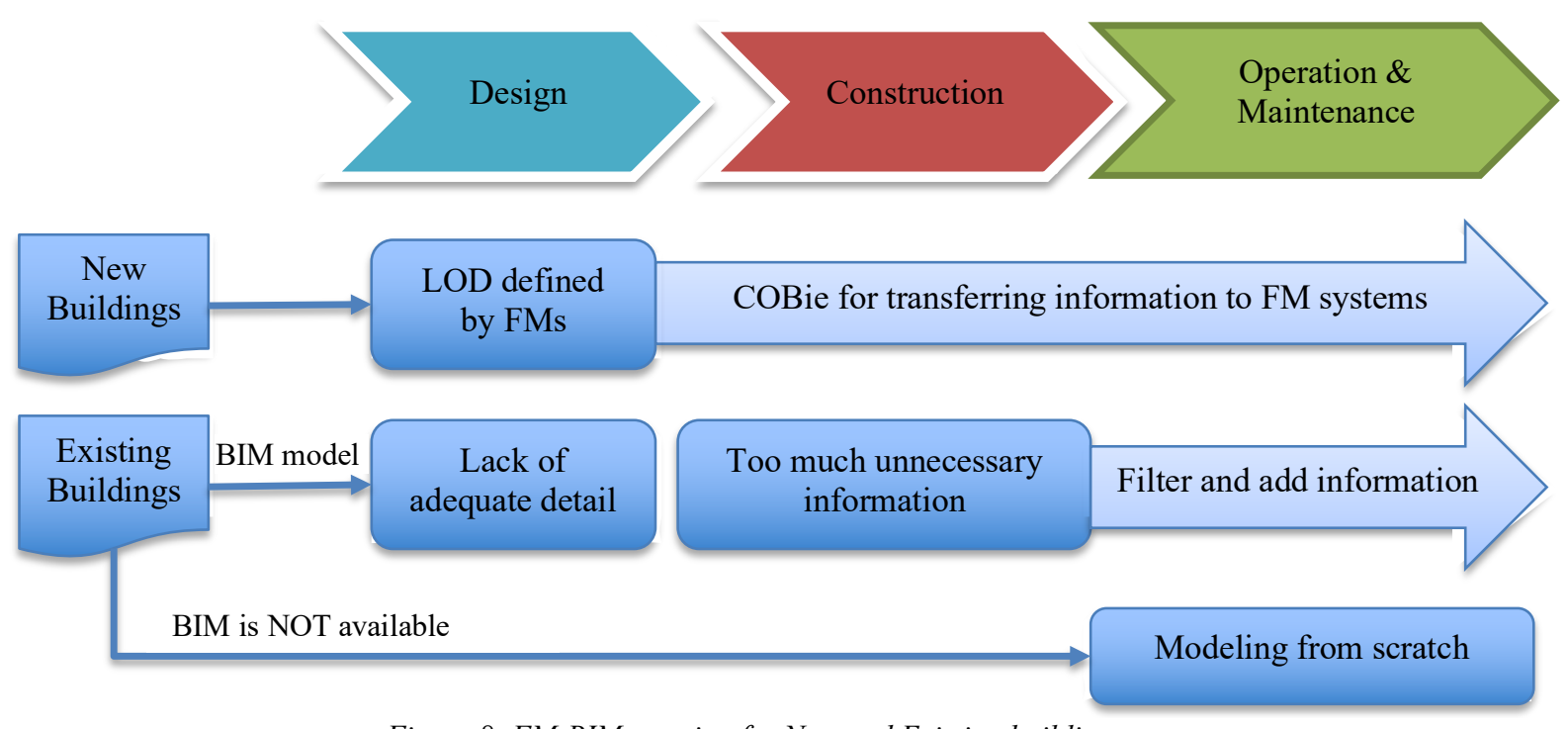

Figure 8: FM-BIM creation for New and Existing buildings

construction phase, the construction model normally contains too much information about construction details that have no relevance to FM, lacks proper definitions for space management, and lacks systems connectivity information and equipment data needed for FM (Sacks et al. 2018). The best way for modelling BIM used for FM tasks in new buildings is to define necessary LOD by FMs in an early phase to be included in their BIM models since BIM offer new opportunities to improve FM tasks and enhance building performance during O\&M phase of the buildings. For existing buildings, this research will assist FMs by defining what information should be made readily available for FM operation.

\section{Conclusions}

In order to use BIM for existing building in O\&M phase, it is absolutely crucial to access appropriate and reliable LOD to operate and maintain equipment and systems efficiently in the buildings. This paper has defined the appropriate LOD for each areas of FM for existing buildings in order to utilize full potentially BIM for FMs in O\&M phase. The results show that more than 60 percent of properties are nonessential for implementing FM tasks. Among 40 percent, "service" category is required specific LOD with more detail. The case study illustrates although the "service" category is the most important one and requires more properties, approximately 60 and 30 percent of properties are missing in TR5 and Gaia respectively. However, the properties for "Shell" and "Equipment \& furnishing" categories are nearly available in both buildings. Concerning properties for each FM areas, warranty start date, warranty end date, assessment date, assessment condition, and service life duration is not required for space or security management purposes, but information about assignable area, net to gross space requirement is important for managing space. Material Safety Data Sheet (MSDS) information is important for safety management area.
Regarding asset, maintenance and energy management, the elements description, where it is installed, manufacturer name, serial number, acquisition date, (nominal power consumption, coefficient of performance in case of a chiller); (nominal air flow rate, fan speed, fan Ext pressure drop in case of a fan); and efficiency, humidifier capacity in case of an air handling unit for each elements are highly important for asset, maintenance and energy management. The case studies also illustrate difficulty to obtain information for TR5 building because the information is not updated. Some equipment like Laser scanning, thermal camera, etc. could be used to obtain these kind of information but it is necessary to evaluate the costs and benefits of acquiring information beforehand. Future research will evaluate the costs and benefits to make decision whether to obtain information or not.

\section{Acknowledgements}

This research was partially supported by funds from the City Hall of Terrassa, Spain.

\section{References}

(AIA), A. I. of A. (2008). "AIA Document E202 TM 2008." Building Information Modeling Protocol Exhibit, (10), 1-9.

Akcamete, A., Akinci, B., and Garrett, J. H. (2010a). "Potential utilization of building information models for planning maintenance activities." Proceedings of the International Conference on Computing in Civil and Building Engineering, 151-157.

Anderson, A., Marsters, A., Dossick, C. S., and Neff, G. (2012). "Construction to operations exchange: Challenges of implementing COBie and BIM in a large owner organization." Construction Research Congress 2012: Construction Challenges in a Flat World, 
Proceedings of the 2012 Construction Research Congress, 688-697.

Arayici, Y., Coates, P., Koskela, L., Kagioglou, M., Usher, C., and O'Reilly, K. (2011). “Technology adoption in the BIM implementation for lean architectural practice." Automation in Construction, 20(2), 189-195.

Babič, N. C., Podbreznik, P., and Rebolj, D. (2010). "Integrating resource production and construction using BIM." Automation in Construction, 19(5), 539-543.

Barnes, S., and Castro-Lacouture, D. (2009). "BIMenabled integrated optimization tool for leed decisions." Proceedings of the 2009 ASCE International Workshop on Computing in Civil Engineering, 258-268.

Becerik-Gerber, B., Asce, A. M., Jazizadeh, F., Li, N., and Calis, G. (2012a). "Application areas and data requirements for BIM - enabled facilities management." Journal of Construction Engineering and Management, 138(3), 431442.

Becerik-Gerber, B., and Rice, S. (2010). "The perceived value of building information modeling in the U.S. building industry." Electronic Journal of Information Technology in Construction, 15, 185-201.

Bortolini, R., and Forcada, N. (2018). "Facility managers ' perceptions on building performance assessment." Front. Eng. Manag, (July).

Bortolini, R., Forcada, N., and Macarulla, M. (2016). "BIM for the integration of Building Maintenance Management: A case study of a university campus." Conference: 11th European Conference on Product \& Process ModellingAt: Limassol, Cyprus.

Boukamp, F., and Akinci, B. (2007). "Automated processing of construction specifications to support inspection and quality control." Automation in Construction, 17(1), 90-106.

Bruno, S., De Fino, M., and Fatiguso, F. (2018). "Historic Building Information Modelling: performance assessment for diagnosis-aided information modelling and management." Automation in Construction, Elsevier, 86(December 2017), 256-276.

Cavka, H. B., Staub-French, S., and Poirier, E. A. (2017). "Developing owner information requirements for BIM-enabled project delivery and asset management." Automation in Construction, Elsevier, 83(September 2016), 169-183.

Chen, W., Chen, K., Cheng, J. C. P., Wang, Q., and Gan, V. J. L. (2018). "Automation in Construction BIM-based framework for automatic scheduling of facility maintenance work orders." Automation in Construction, Elsevier, 91(February), 15-30.

Chew, M. Y. L., Tan, S. S., and Kang, K. H. (2004). "A technical evaluation index for curtain wall and cladding facades." Struct. Surv., 36(12), 4605-4609.

Cho, Y. K., Alaskar, S., and Bode, T. A. (2010). "BIMintegrated sustainable material and renewable energy simulation." Construction Research Congress 2010: Innovation for Reshaping Construction Practice - Proceedings of the 2010 Construction Research Congress, 288-297.

Dias, P., and Ergan, S. (2016). "The Need for Representing Facility Information with Customized LOD for Specific FM Tasks." Construction Research Congress 2016: Old and New Construction Technologies Converge in Historic San Juan - Proceedings of the 2016 Construction Research Congress, CRC 2016, 2563-2572.

Donath, D. (2009). "No Title." Bauaufnahme und Planung Im Bestand: Grundlagen - Verfahren Darstellung - Beispiele.

Eastman, C. M., Teicholz, P., Sacks, R., and Liston, K. (2008). "No Title." BIM Handbook: A Guide to Building Information Modeling for Owners, Managers, Architects, Engineers, Contractors, and Fabricators, 450.

Gursel, I., Sariyildiz, S., Akin, O., and Stouffs, R. (2009). "Modeling and visualization of lifecycle building performance assessment." Advanced Engineering Informatics, 23(4), 396-417.

Hwang, S., and Liu, L. Y. (2010). "BIM for integration of automated real-time project control systems." Construction Research Congress 2010: Innovation for Reshaping Construction Practice - Proceedings of the 2010 Construction Research Congress, 509-517.

IFMA. (2016). "FM Standards: The Business Case for Compliance \& ISO Management System Standards for FM." IFMA's World workplace.

Jiao, Y., Wang, Y., Zhang, S., Li, Y., Yang, B., and Yuan, L. (2013). "A cloud approach to unified lifecycle data management in architecture, engineering, construction and facilities management: Integrating BIMs and SNS." Advanced Engineering Informatics, 27(2), 173188.

Kiziltas, S., and Akinci, B. (2010). "Lessons learned from utilizing building information modeling for construction management tasks." Construction Research Congress 2010: Innovation for Reshaping Construction Practice - Proceedings of the 2010 Construction Research Congress, 
318-327.

Leite, F., Akcamete, A., Akinci, B., Atasoy, G., and Kiziltas, S. (2011). "Analysis of modeling effort and impact of different levels of detail in building information models." Automation in Construction, 20(5), 601-609.

Lijun, S., Edirisinghe, R., and Goh, Y. M. (2016). “An Investigation of BIM Readiness of Owners and Facility Managers in Singapore: Institutional Case Study An Investigation of BIM Readiness of Owners and Facility Managers in Singapore : Institutional Case study." (October), 259-270.

Liu, R., and Issa, R. R. A. (2016). "Survey: Common knowledge in BIM for facility maintenance." Journal of Performance of Constructed Facilities, 30(3).

Mill, T., Alt, A., and Liias, R. (2013). "Combined 3D building surveying techniques-Terrestrial laser scanning (TLS) and total station surveying for BIM data management purposes." Journal of Civil Engineering and Management, 19(SUPPL.1), S23-S32.

Motawa, I., and Almarshad, A. (2013). "A knowledgebased BIM system for building maintenance." Automation in Construction, 29, 173-182.

Pärn, E. A., Edwards, D. J., and Sing, M. C. P. (2017). "The building information modelling trajectory in facilities management: A review." Automation in Construction, 75, 45-55.

Pishdad-Bozorgi, P., Gao, X., Eastman, C., and Self, A. P. (2018). "Planning and developing facility management-enabled building information model (FM-enabled BIM)." Automation in Construction, Elsevier, 87(February 2017), 22 38.

Sacks, R., Eastman, C., Lee, G., and Teicholz, P. (2018). BIM Handbook.

Sacks, R., Radosavljevic, M., and Barak, R. (2010). "Requirements for building information modeling based lean production management systems for construction." Automation in Construction, 19(5), 641-655.

Sacks, R., Treckmann, M., and Rozenfeld, O. (2009). "Visualization of work flow to support lean construction." Journal of Construction Engineering and Management, 135(12), 13071315.

Sattenini, A., Azhar, S., and Thuston, J. (2011). "Preparing a Buindling Information Model for Facility Maintenance and Management." Proceedings of the 28th International Symposium on Automation and Robotics in Construction, Seoul, South Korea, 150-155.

Shohet, I. M., Lavy-Leibovich, S., and Bar-On, D.
(2003). "Integrated maintenance monitoring of hospital buildings." Construction Management and Economics, 21(2), 219-228.

Singh, V., Gu, N., and Wang, X. (2011). "A theoretical framework of a BIM-based multi-disciplinary collaboration platform." Automation in Construction, 20(2), 134-144.

Stumpf, A., Kim, H., and Jenicek, E. (2009). "Early design energy analysis using bims (building information models)." Building a Sustainable Future - Proceedings of the 2009 Construction Research Congress, 426-436.

Teicholz, E. (2013a). "Bridging the AEC/FM technology gap." IFMA Facility Manage J, 1-8.

Terreno, S., Anumba, C. J., Gannon, E., and Dubler, C. (2015). "The benefits of BIM integration with facilities management: A preliminary case study." Congress on Computing in Civil Engineering, Proceedings, 675-683.

Thabet, W., Lucas, J., and Johnston, S. (2016). "A Case Study for Improving BIM-FM Handover for a Large Educational Institution." Construction Research Congress 2016: Old and New Construction Technologies Converge in Historic San Juan - Proceedings of the 2016 Construction Research Congress, CRC 2016, 2177-2186.

The National Institute of Building Sciences. (2013). "The COBie Guide | The National Institute of Building Sciences."

Volk, R., Stengel, J., and Schultmann, F. (2014). "Building Information Modeling (BIM) for existing buildings - Literature review and future needs." Automation in Construction, Elsevier B.V., 38, 109-127.

Weygant, R. S. (2011). "BIM content development: Standards, strategies, and best practices (1)." BIM Content Development: Standards, Strategies, and Best Practices.

Zou, Z., and Wang, Y. (2009). "Framework of spatial decision support system for large-scale public building evacuation." Proceedings of the 2009 WRI Global Congress on Intelligent Systems, GCIS 2009, 352-356. 